\title{
The Motivational Basis of Concessions and Compromise: Archival and Laboratory Studies
}

\author{
Carrie A. Langner \\ University of California, Berkeley
}

\author{
David G. Winter \\ University of Michigan
}

\begin{abstract}
A content analysis system for measuring positive concessions (offering concessions) and negative concessions (rejecting offered concessions) was introduced and validated through an archival study of government-to-government documents from 4 crises, 2 of which escalated to war and 2 of which were peacefully resolved. In the archival documents, concession making was positively associated with affiliation motivation and negatively associated with power motivation. A 2nd, laboratory experimental study confirmed these relationships and demonstrated priming effects of motive imagery and concession making, in a received diplomatic letter, on participants' responses. Finally, the motive imagery and concessions scores in participants' responses were related in predicted ways to their policy choices.
\end{abstract}

Not every conflict or crisis escalates to war. Even when there may seem to be no way out, a way is sometimes found. For example, at the height of the Cuban Missile Crisis of October 1962, U.S. President John F. Kennedy estimated the chances of nuclear war as "somewhere between one out of three and even" (Sorenson, 1965, p. 705). Yet Soviet President Nikita Khrushchev and Kennedy worked their way out of a nuclear box, each making concessions while resisting the siren calls from some advisors to "stand firm" or even begin military action (Fursenko \& Naftali, 1997).

In March of that same year, French President Charles de Gaulle, who had been brought to power in 1958 by a virtual military coup in support of a continued colonialist "Algérie française," successfully negotiated Algerian independence. And 6 months later, on a visit to France's ancient enemy Germany, de Gaulle several times spoke, in German, of "the great German people," repeatedly exclaiming, with his arms raised above his head, "Es lebe Deutschland!" ["Long live Germany!"] (de Gaulle, 1970, pp. 6-9, 15; see also La Couture, 1991, p. 341).

Finally, consider the annus mirabilis that began in February 1989. On the 6th of that month, the government of Poland refrained from introducing martial law to suppress dissent (as it had in December 1981) and instead began roundtable talks that led to open elections. In October, the East German regime responded to massive demonstrations in East Berlin and Dresden, not with force and repression (as in 1953), but with discussions that began the

Carrie A. Langner, Department of Psychology, University of California, Berkeley; David G. Winter, Department of Psychology, University of Michigan.

This article is based on Langner (1997). We are grateful to Jill Greenlee and John Herrington for assistance in scoring concessions and to Eileen Zurbriggen and Cheryl Rusting for assistance in scoring motive imagery. process of peaceful unification of East and West Germany. In November, the "velvet revolution" in Czechslovakia led to the end of one-party rule and the promise of elections. And in February 1990, South African nationalist party leader Frederik de Klerk announced the "unbanning" of the African National Congress, released Nelson Mandela from prison, and took the first steps toward negotiating a peaceful transfer of power from the White minority to the Black majority.

In 1979, Hans Morgenthau, the great scholar of international relations, confessed to a friend: "I am extremely pessimistic. In my opinion the world is moving ineluctably toward a third world war-a strategic nuclear war. I do not believe that anything can be done to prevent it" (Boyle, 1985, p. 73). Three months later, George Kistiakowsky (a chemist and presidential science advisor who helped to develop the atomic bomb) told a Harvard audience that "I personally think that the likelihood for an initial use of nuclear warheads is really quite great between now and the end of this century" (Boyle, 1985, p. 73). Yet the millennium has come, and we are still here, without the use (so far) of nuclear warheads or a third world war.

\section{Concessions, Compromise, and the Resolution of Conflict}

\section{The Necessity of Concessions}

If wars are frequent and human beings are often violent toward each other, it is also true that humans can (and often do) compromise to avoid conflict escalation and war. The essence of every conflict is a clash of two or more incompatible desires, claims, or principles: One party (person, group, or nation-state) wants, claims, or supports something that is also wanted, claimed, or opposed by another party. For conflicts to be resolved (at least in the absence of some creative win-win option), therefore, one side must make a concession, giving up some previously announced claim (also called a conciliatory initiative; see Pruitt, 1998, p. 490). Concessions may be mutual. They may emerge from discussion and negotiation, the threat of force, or the suggestion of a third party. They may be motivated by the highest ethical principles or 
driven by fear of consequences. They may be disguised or "sweetened" by processes of reframing, redefinition, or other creative negotiation and mediation techniques (Fisher \& Ury, 1991; Pruitt, 1983; Rubin. 1981). In every case, however, concessions are the fundamental building block of conflict resolution.

To be successful, of course, concessions must ultimately be reciprocated. The course of negotiations, in international diplomacy as well as in the laboratory, usually involves the orchestration of a complex combination of elements (demands, threats, promises, concessions, and even third-party interventions) into overall strategies (see Patchen, 1987; also Carnevale \& Pruitt, 1992; Lebow, 1996, chapters 6-8; Pruitt, 1998; Rubin, 1994). Still, one side usually has to take the first step. Thus, on October 24, 1962. Khrushchev answered Kennedy's proclamation of a limited blockade with defiance: "The Soviet government cannot instruct the captains of Soviet vessels bound for Cuba to observe the instructions of American naval forces blockading that island" (Fursenko \& Naftali, 1997, p. 256). On the next day, however, he told the meeting of the Presidium of the Soviet Communist Party that he would order four ships that were transporting missiles to Cuba to turn around and would propose the removal of missiles in exchange for an American pledge not to invade Cuba-this set in motion the exchange of messages between Khrushchev and Kennedy that ultimately shaped the resolution of the crisis.

It is important to realize that concessions may not always be appropriate, wise, or good in the retrospective view of history. Thus, although most people would agree that the mutual concessions that resolved the Cuban Missile Crisis may have prevented a thermonuclear holocaust, many would argue that the one-sided concessions of the 1938 Munich agreement only postponed (and may even have made more likely) the outbreak of World War II.

\section{The Costs of Concessions}

Concessions usually involve costs, both real and symbolic. Although concessions may be appropriate under certain conditions (Morgenthau, 1967, pp. 61-62; see also Jervis, 1976), an insatiable and powerful opponent may respond with further demands instead of a reciprocal concession (Lebow, 1996, p. 78). Thus, making a concession may not ultimately prevent a war. Over 2,000 years ago, the Roman lawyer and political leader Cicero (trans. 1953 , p. 527) asked, "What can be done against force without force?" Schmookler's (1984) analysis of the "ways of power" suggests that the reply should be, "Not much."

In the minds of several generations of American leaders, the apparent failure of the 1938 Munich and 1945 Yalta agreements thoroughly discredited concessions and appeasement. As Clark Clifford (1946/1968) advised President Harry Truman in a 1946 memorandum that was to guide U.S. policy toward the Soviet Union in the late 1940s: "The language of military power is the only language the disciples of power understand. . . . Compromise and concessions are considered, by the Soviets, to be evidence of weakness and they're encouraged by our 'retreats' to make new and greater demands" (p. 477).

Concessions may be misinterpreted as signs of weakness, capitulation, or collapse (Schelling, 1963, pp. 71, 111). For example, during the Cuban Missile Crisis, when U.S. Secretary of State Dean Rusk learned that the ships had turned back from the blockade line. he exclaimed to National Security Advisor McGeorge
Bundy, "We are eyeball to eyeball and the other fellow just blinked!' (Rusk, 1990, p. 237), which seemed to frame Khrushchev's action in terms of the adolescent game of "chicken." At a more symbolic level, making concessions may suggest passivity and low prestige (see Morley \& Stephenson, 1977, pp. 40-41, on image loss). Because power relations and gender are often taken as metaphors for each other (Scott, 1986; see also Rank, 1914), many male political leaders might even (albeit not always consciously) view concessions as threats to their sexual orientation and gender identity.

Finally, concessions may be impossible to sell to constituents (Lebow, 1996, pp. 12, 95, 104). In fact, Khrushchev's concessions during the Cuban Missile Crisis were one reason his opponents removed him from office two years later. As one of his most severe critics claimed at that time, "We had to accept every demand and condition dictated by the U.S. . . This incident damaged the international prestige of our government, our party, our armed forces, while at the same time raising the authority of the United States" (Fursenko \& Naftali, 1997, p. 354).

If we understood the psychological factors that led political leaders to make concessions instead of escalations, we might be able to encourage more felicitous outcomes like the examples mentioned at the beginning. To that end, this article describes two studies, one archival and one laboratory, designed to identify motivational factors associated with the choice of concession and compromise, rather than escalation and aggression, in a conflict situation. We also wanted to explore the relation between people's images of concession and their actual offering of concessions.

\section{Psychological Research on Concessions}

Although the word concessions appears only three times in the index of the most recent Handbook of Social Psychology (Gilbert, Fiske, \& Lindzey, 1998) and not at all in either of the most recent handbooks of personality research, the topic of concession making involves a wide variety of cognate concepts and literature, including, at the least, the following: bargaining, negotiation, decision making, conflict resolution, power and dominance, aggression, altruism, trust, deference, conformity and compliance, submission, and appeasement. However, the core generalizations about the antecedents of making versus withholding concessions are drawn from the enormous literature on social conflict and negotiation. Much of the review that follows is based on Carnevale and Pruitt (1992), Druckman (1994, 1997), Pruitt (1998), Pruitt and Rubin (1986), and Thompson (1990). (See Morley \& Stephenson, 1977, for a review of earlier work; see Kriesberg, 1998, and Kriesberg \& Thorson, 1991, for reviews that draw extensively on the history of international relations.)

\section{Structural and Situational Factors}

The likelihood of one or both parties offering concessions in a conflict or negotiation situation is affected by many structural and situational factors, such as the following: the number of parties (bilateral vs. multilateral); the institutional framework (e.g., judi-

\footnotetext{
${ }^{1}$ Cicero's letter, written in 44 B.C.E., was addressed to his ally Cassius during the hectic months after the assassination of Julius Caesar.
} 
cial vs. religious atonement); the site and physical setting of negotiations (e.g., the "shape of the table" that was so controversial in the Vietnam peace negotiations in the early 1970s); the agenda, decision rules, and normative structure; the public visibility of the negotiating parties (e.g., through presence of the media or other audience); the existence of deadlines and time pressures; the number and nature of issues under discussion; and the initial positions of the parties and consequent distance between these positions. More abstractly, the incentive structure (or "payoff matrix") represents the possible gains and losses to each party, as a consequence of their combined decisions and responses.

\section{Relational Factors}

Most negotiating parties have a previous history of negotiating with each other and with other parties; frequently this history is said to furnish lessons or heuristics that are applied, rightly or wrongly (Khong, 1992; Neustadt \& May, 1986), to frame the current negotiation. Depending on the interests of each side, it may be easier or harder to discover (or construct) common overarching interests that can help to bridge areas of disagreement. At any point during the actual negotiations, the cumulative history of the current process itself-the complex and dynamic sequence of requests, demands, threats, concessions, compromises, reciprocity (or its lack)-exerts powerful effects on the next steps (Morley \& Stephenson, 1977, pp. 85-101). Thus, we can speak of ripeness (when the "time is ripe" for intervention, for making a concession, for compromise, etc.; see Kriesberg \& Thorson, 1991) and turning points in the negotiation process (Druckman, 1997, p. 99; 2000).

\section{Individual Factors}

Individual negotiating parties and individual persons differ in their willingness to make concessions. For example, the gender and cultural backgrounds of negotiators affect how they negotiate. Bureaucratic politics-that is, the perceived domestic social, economic, and political constituencies and support structures (and opposition structures) of each party-often exert substantial effects on ostensibly external negotiations. And the kind of advance preparation negotiators undertake (thinking about strategy vs. issues) affects their subsequent level of compromise behavior. Attributions, especially about the situation and traits of the negotiating counterpart, are also critically important (Morris, Larrick, \& Su, 1999).

Orientation. The meta-analysis of compromising behavior in negotiation by Druckman (1994) suggested that individual differences in orientation (competitive vs. cooperative) is one of the most powerful predictors of negotiation behavior. The concept of psychological orientation was developed by Deutsch (1982), who defined it as an amalgam of cognitive, motivational, and moral elements. Thus a cooperative (vs. competitive) orientation would include perception of the negotiation process as non-zero-sum (vs. zero-sum), the other side as a partner (vs. opponent or enemy), and the best outcome as maximum joint gain. It would include trust and the desire for affiliation (vs. aggressive or dominance motives) and be grounded in an egalitarian (vs. exploitative) moral stance. In most laboratory research, orientations are directly manipulated by experimental instructions, although they are sometimes (e.g.,
Druckman, 1967) measured as prior individual difference variables.

Personality factors. Deutsch's (1982) use of a variety of different individual difference constructs to define and describe cooperative and competitive orientations has certainly enriched their connotative meaning. On the other hand, this inclusiveness has led to a certain operational confusion and proliferation. Indeed, as Grzelak (1994, p. 192) noted, orientation is often measured by outcome-a procedure that confuses independent and dependent variables and invites circularity. It is useful, therefore, to review the literature relating several specific personality variables, measured by methods with established validity, that could plausibly be considered as components of the cooperative versus competitive orientation. $^{2}$

Personality traits are related to negotiating behavior, in real life as well as in laboratory studies. Thus, in an archival study of 20th-century American presidents and secretaries of state, Etheredge (1978) demonstrated that extraverts advocated force, whereas introverts were inclined to promote compromise. Several cognitive variables are related to cooperative behavior, especially in situations of crisis and negotiation (see Voss \& Dorsey, 1992; Winter, 1992). Archival studies by Suedfeld and his associates (Suedfeld \& Tetlock, 1977; Tetlock, 1979; Wallace, Suedfeld, \& Thachuk, 1993) demonstrated the connection between integrative complexity and peaceful resolution of international crises. In contrast, right-wing authoritarianism is associated with escalation in laboratory simulations (Altemeyer, 1996, pp. 130-136).

Motives. Several different kinds of studies have linked cooperation and competition to one particular element of personality, namely motives (particularly implicit motives; see McClelland, Koestner, \& Weinberger, 1989). Implicit motives are measured through content analysis of verbal material, using the empirically derived content-analysis scoring systems developed by McClelland and his colleagues (see Winter, 1998; also Smith, 1992, for a discussion of methodological and psychometric issues). For example, power motivation (a concern for impact, prestige, and reputation) is often associated with verbal and physical aggression (see Winter, 1996, chapter 5) and an exploitative, aggressive negotiation style (see Schnackers \& Kleinbeck, 1975; Terhune, 1968, 1970). In contrast, affiliation motivation (a concern for close, friendly relations among people and groups) is often linked to cooperative behavior, at least under "safe" conditions. Table 1 provides a brief description of the content-analysis scoring and associated actions and outcomes for these two motives.

Motivation should affect concession making: directly, in terms of leading people to make (or emit) concessions, and indirectly, both by affecting people's perceptions, construals, and evaluations of others' responses and finally by guiding their own responses to these responses. Studies in which leaders' motives are measured at a distance have shown that leaders scoring high in power motiva-

\footnotetext{
${ }^{2}$ Space does not permit a review of the age-old debate about the relative importance of structural and situational versus individual factors in determining political and social outcomes. Greenstein (1969/1987, Chap. 2) suggested that the personalities of individual actors do play an important role in situations that are new or unstructured, are emotionally arousing, and involve unclear expectations. All of these features are certainly characteristic of most conflict situations.
} 
Table 1

Behavior Correlates of the Affiliation and Power Motives

\begin{tabular}{|c|c|c|}
\hline Motive characteristic & Affiliation motive & Power motive \\
\hline Verbal images scored & $\begin{array}{l}\text { Concern about establishing, maintaining, } \\
\text { or restoring friendly relations among } \\
\text { persons or groups }\end{array}$ & $\begin{array}{l}\text { Concern about having impact, control, } \\
\text { or influence on another person, } \\
\text { group, or the world at large by } \\
\text { strong forceful actions, controlling } \\
\text { or regulating others, trying to } \\
\text { influence or persuade, unsolicited } \\
\text { helping, or acquiring prestige }\end{array}$ \\
\hline Actions & $\begin{array}{l}\text { Cooperative and friendly when "safe"; } \\
\text { defensive and even hostile under threat }\end{array}$ & $\begin{array}{l}\text { Depending on level of responsibility, } \\
\text { either successful leadership and } \\
\text { high subordinates' morale or } \\
\text { profligate impulsivity }\end{array}$ \\
\hline Negotiating style & $\begin{array}{l}\text { Cooperative when safe; defensive and } \\
\text { hostile under threat }\end{array}$ & Exploitative, aggressive \\
\hline Seeks help from & Friends and similar others & Political experts \\
\hline
\end{tabular}

tion tend to be aggressive and involve their countries in war (Winter, 1980, 1992). Finally, in content-analysis studies of archival materials such as cultural documents and government messages, high levels of power motivation are associated with subsequent war entry, whereas high levels of affiliation motivation are often associated with avoidance of war or at least ending war (Winter, 1993, 1997).

A laboratory study of conflict escalation by Peterson, Winter, and Doty (1994) showed that when one side expressed higher power and lower affiliation motive imagery (vs. lower power and higher affiliation motive imagery), the other side responded in kind (higher power and lower affiliation), as well as with higher levels of aggression. ${ }^{3}$

Overall, then, there is strong ground for believing that the affiliation motive is at the core of the cooperative orientation and that, in negotiation situations, it should therefore be associated with making concessions and accepting the concessions of others. In contrast, the power motive should be an important component of the competitive orientation and should be associated with resistance to making concessions, or rejecting concessions made by the other side. The research reported in this article was designed to explore these general hypotheses in two very different ways: (a) through content analysis of archival data drawn from actual diplomatic negotiations and (b) through a laboratory simulation of negotiation during the Cuban Missile Crisis. We agree with Grezelak's (1994, p. 260) call for integration of laboratory research on conflict and cooperation orientations with field or archival studies of "real-life phenomena," to demonstrate that our theoretical concepts and measures are truly relevant to social reality (see also the earlier integrative review by Patchen, 1987). Thus, we proposed to relate concession making to the affiliation and power motives-measured in both laboratory tests and archival government documents by the same content-analysis systems.

The concept of motive imagery, as used in this article, deserves a brief conceptual discussion. We used scoring systems that were developed in the tradition of personality research, where individual Thematic Apperception Test protocols were content analyzed to measure the motives of individual persons (see Winter, 1998). When applied to speeches, diplomatic communications, and other documents usually produced by collectivities, we cannot be sure that we are measuring the motives of the persons whose name is signed to the documents. Rather, we may be measuring the motives of loosely defined leadership collectivities, or even other, nonmotivational concepts (see Winter, 1993, p. 535, for a detailed discussion). From an empirical perspective, the important question is whether these scores predict the same kinds of actions and outcomes as they do among individuals. In this article, therefore, we used the theoretically agnostic terms motive imagery and documents instead of motives and persons.

\section{Study 1: Developing and Validating a Coding System for Concessions}

What is a concession, and how can it be measured in both archival and laboratory research? On the one hand, the diplomatic history literature contains many examples but few precise operational definitions or procedures for quantification. On the other hand, laboratory researchers often measure concessions by seemingly superficial variables such as the giving or exchanging of small sums of money or "points." Although these measures are precise, they do not necessarily have anything to do with concessions in the real world of international relations (or, for that matter, even significant interpersonal relationships). For the present research, therefore, we decided to construct a new measure of concession making that could be used in both archival and laboratory studies.

\section{Measuring Concessions: A Grounded Theory Approach}

On the basis of a review of the political and psychological literature (e.g., Etzioni, 1967; Kriesberg \& Thorson, 1991, pp. 264-265), as well as intensive comparison of diplomatic documents from a crisis that escalated to war and a similar crisis that was peacefully resolved, Langner (1997) first developed a system for coding concessions on the basis of verbal content. The two crises were the outbreak of war between the United States and Mexico and the peaceful settlement of the U.S. dispute with Great

\footnotetext{
${ }^{3}$ This result is consistent with the finding of Wrightsman, Baxter, Nelson, and Bilsky (1972) that cooperation is more likely when the "other" is portrayed as cooperative rather than competitive.
} 
Britain about the Oregon boundary. Both were related to the American sense of Manifest Destiny and territorial expansion to the Pacific Coast, both were handled by the administration of President James K. Polk, and both occurred during 1845 and the first half of 1846 (see Winter, 1997).

The concessions scoring system is organized in terms of four positive categories and four parallel negative categories. The positive categories all involve proposing or accepting concessions in a dispute:

1. Proposals for procedural arrangements that will facilitate negotiation and peaceful resolution of a crisis;

2. Suggestions or offers of mediation by some third party (cf. Rubin, 1981);

3. Taking, or offering to take, some specific act of de-escalation (can be subdivided into unilateral and reciprocal de-escalation acts); and

4. Accepting a concession (Categories $1-3$ above) made by the other side.

The negative categories are parallel to the positive ones, but involve rejecting concessions or escalating conflict:

1. Declining or rejecting a procedural proposal made by the other side;

2. Refusing a suggestion or offer of mediation;

3. Taking, or threatening to take, some specific act of escalation (can be subdivided into unilateral and reciprocal escalation); and

4. Rejecting a proposed concession (positive Category 3 above) made by the other side.

Further definitions and examples of these categories are given in Table 2. In applying the system, the sentence is the unit of scoring. The eight categories are logically independent of each other, which means that, in principle, each sentence could be scored for the presence of any category or categories.

\section{Cross-Validating the Concessions Measure in Archival Documents From Four Crises}

The first study was designed for two purposes: (a) to establish the real-world validity of the concessions scoring system and (b) to explore the relationships between affiliation and power-motive imagery and concessions. To cross-validate the scoring system, diplomatic documents and other written government-to-government communications from two additional pairs of crises were mixed together and blindly scored for concessions and motive imagery. Each pair consisted of a peacefully resolved crisis and a similar crisis (involving approximately the same countries, during the same historical era) that escalated to armed conflict. This method has been characterized by George (1979) as structured focused comparison (or disciplined configurative), which is a type of historically grounded theory development: Comparable individual cases, with different outcomes, are described, analyzed, and explained in terms of theoretically relevant general variables.

The first matched pair consisted of the 1938 crisis over German demands to annex parts of Czechoslovakia, which was peacefully resolved at the Munich series of conferences among Germany, Great Britain, France, and Italy that averted (perhaps unwisely, and in any case only for a few months) war. It was paired with the 1939 crisis over German demands to annex Danzig and modify the German-Polish boundary. That crisis ended on September 1, 1939, with the outbreak of World War II, as Germany invaded Poland. Both of these crises arose from German expansion and involved

Table 2

Coding System for Scoring Concessions

\begin{tabular}{ll}
\hline Category & Definition and example \\
\hline
\end{tabular}

Positive categories
1. Procedural
2. Mediation
3. De-escalation

4. Accept

Oppose procedural

1. Oppose procedural

2. Oppose mediation

3. Escalation

4. Reject
Proposals for procedural arrangements that will facilitate negotiation and peaceful resolution of a crisis. Example: "We are prepared to set one single date if that would facilitate the task."

Suggestions or offers of mediation by some third party. Example: "If desired, I am willing to arrange for the representatives of a third party at the discussion."

Unilateral: Taking, or offering to take, some specific act of de-escalation, not contingent on response of other side. Example: "I am willing to eliminate harmful military expenditures and focus on maintaining peaceful relations between our countries."

Reciprocal: Taking, or offering to take, some specific act of de-escalation, contingent on response of other side. Example: "I assure you that if you adhere to the tenets of our agreement, eliminating the specified weapons, we will not attack."

Accepting a concession (Categories 1-3 above) made by the other side. Example: "I will agree to your public declaration that you are not supplying weapons and will agree not to invade."

\section{Negative categories}

Declining or rejecting a procedural proposal (positive Category 1 above) made by the other side. Example: "Further communication between our diplomats is proving unproductive at this point, and therefore our representatives will be returning home."

Refusing a suggestion or offer of mediation. Example: "This government is not willing to involve a third party in the current dispute."

Unilateral: Taking, or threatening to take, some specific act of escalation, not contingent on response of other side. Example: "We are prepared to halt your military shipments and will do so by stopping and examining your ships."

Reciprocal: Taking, or threatening to take, some specific act of escalation, contingent on response of other side. Example: "If you break our agreement of nonviolence, we will retaliate."

Rejecting a proposed concession (positive Category 3 above) made by the other side. Example: "I cannot accept your promise of not supplying weapons and therefore will not guarantee anything." 
Great Britain and Germany as major antagonists. The other matched pair consisted of two crises over Cuba that involved the United States and the former Soviet Union: the disastrous 1961 Bay of Pigs invasion of Cuba by Cuban exiles, who were in fact organized, financed, and directed by the United States (Fursenko \& Naftali, 1997), and the October 1962 Cuban Missile Crisis, in which the United States and Soviet Union narrowly averted nuclear war. Although the Bay of Pigs lasted for only a few days, it was clearly a war, complete with bombing, aerial combat, and intense ground fighting between the Cuban army and the American-trained and American-supplied invaders.

The first hypothesis of the archival study is that the documents from the two peacefully resolved crises will score higher in total and positive concessions and lower in negative concessions than documents from the two war crises. The second hypothesis is that across all documents, the number of positive concessions will be positively correlated with affiliation motivation and negatively correlated with power motivation and that for negative concessions, these correlations will be reversed.

\section{Method}

Selection of documents. The first step we took was to establish precise beginning and ending dates. On the basis of the discussion in Watt (1989), the Munich crisis was considered to have begun on May 22, 1938, and ended on September 29, 1938, whereas the Poland crisis began on March 31, 1939 and ended on September 3, 1939. Dates for the Bay of Pigs (April 6-22, 1961) and Cuban Missile Crisis (October 22-28, 1962) were based on the dates of the first and last documents available for scoring. ${ }^{4}$

For each crisis, all documents representing official government public statements or government-to-government communications were drawn from the collection of documents assembled by Winter (1997) from published archival sources (see Appendix A for a list of all documents). This yielded 32 written government-to-government communications for the Munich crisis and 16 for Poland (taken from U.S. Department of State, 1949, and Woodward \& Butler, 1949-1954). For the two U.S.-Soviet crises involving Cuba, the written government-to-government communications (from U.S. Department of State, 1973) were supplemented by two public statements by President John F. Kennedy (one speech and one press conference transcript) and three official Soviet public statements, for a total of seven Bay of Pigs documents and 12 Cuban Missile Crisis documents. Within each of the paired crises, the documents used were comparable: verbatim government-to-government communications for Munich and Poland and government-to-government communications plus public statements for the Bay of Pigs and Cuban Missile Crisis.

To the extent that we were able to match both the nature of the crises and the type of documents scored within each pair, within-pair differences can be attributed (whether as cause or effect) to the different outcomes-peace or war $\rightarrow$ of the two crises.

Scoring of documents. Documents from all four crises were mixed together in random order and scored for concessions by two scorers who had been trained by Carrie Langner. To avoid bias, scoring of concessions was done by two scorers who were unaware of the purpose and hypotheses of the research and who had little knowledge of the four specific crises. The scorers were trained in the use of the scoring system by Langner.

On a portion of these documentary materials that had also been scored by Langner, these two scorers attained category agreement figures (see Smith, 1992, p. 529) with Langner of .75 and .63. Both scorers scored all documents, resolving all disagreements after discussion. Because the documents varied in length, the raw concessions scores for each document were divided by the number of words and multiplied by 1,000 to give a figure of concessions per 1,000 words. Finally, subtracting negative concessions from positive concessions scores gave a net concessions score.
These documents had previously been scored for affiliation and powermotive imagery according to the integrated running-text scoring system (Winter, 1991) as a part of Winter's (1997) study, by a trained scorer who was blind to the hypotheses and the historical details of the crises and who had previously demonstrated high reliability (category agreement $\geq .85$ ) on materials precoded by expert scorers. Scores for each motive were also expressed in terms of images per 1,000 words. To avoid the theoretical issue of whether impersonal documents or their collective authors can have motives or motivation (as individual persons do; see Winter, 1993), as well as the conceptual status of the motive imagery measures, we used the theoretically more neutral term motive imagery to refer to these scores.

\section{Results}

Validity of the concessions measure. Descriptive statistics for all variables, for each crisis, are presented in Table 3. Two-way analyses of variance, with crisis outcome (war vs. peace) and crisis era (1930s vs. 1960s) as main factors, were carried out on the concessions scores. The results show only a trend in the predicted direction for positive concessions, peacefully resolved crises were higher, $F(1,63)=2.26, p=.138$; but significant predicted effects for negative concessions, war crises were higher, $F(1,63)=10.05$, $p=.002$; and net concessions, peace crises were higher, $F(1$, $63)=5.65, p=.021$. There was also a near-significant main effect for era on positive concessions-the 1930 s crises were higher, $F(1$, $63)=3.60, p=.063$. Only one Outcome $\times$ Era interaction was of borderline significance: The war-peace difference in negative concessions was greater for the two 1930s crises than for the two crises of the 1960s, $F(1,63)=3.82, p=.055$.

Overall, then, the concessions scores differentiate the war and peace crises of both historical eras in the predicted ways. In one sense, these initial results may seem obvious because, almost by definition, peaceful crisis resolution involves one or both sides making positive concessions, and war results from negative concessions. The real point of this first study, however, was to demonstrate the validity of the concessions scoring system on real archival material drawn from major international crises.

The trend for documents from the two U.S.--Soviet crises of 1961-1962 to contain fewer positive concessions than the two British-German crises from 1938-1939 may be due to many factors: the much more protracted nature of the Munich and Poland crises compared with the two Cuban crises, differences in the nature and number of issues at stake, and the historical differences in government-to-government communication technology and style.

Motive imagery and concessions. Table 4 shows the relationship between motive imagery scores and both kinds of concessions scores, across all 67 documents from the four crises. As shown in the top part of the table, affiliation motive imagery is positively

\footnotetext{
${ }^{4}$ The first air strikes occurred on April 15. The actual invasion began on April 17 and effectively ended on April 19. Because of a paucity of official government-to-government documents, as well as public statements, it was necessary to include documents through April 22, by which time Kennedy was already commissioning an investigation of the failed operation (Kornbluh, 1998, pp. 303-320). Because this study was designed not to predict the outbreak of war but rather to validate the concessions scoring system, this should not be a problem. One would certainly predict that communications during a war itself, like communications before the war, contain few positive concessions.
} 
Table 3

Descriptive Statistics for Concessions in Documents From Four Crises

\begin{tabular}{|c|c|c|c|c|c|c|c|}
\hline \multirow[b]{2}{*}{ Crisis } & \multirow[b]{2}{*}{$n$} & \multicolumn{2}{|c|}{$\begin{array}{c}\text { Positive } \\
\text { concessions }\end{array}$} & \multicolumn{2}{|c|}{$\begin{array}{c}\text { Negative } \\
\text { concessions }\end{array}$} & \multicolumn{2}{|c|}{$\begin{array}{c}\text { Net } \\
\text { concessions }^{\mathrm{a}}\end{array}$} \\
\hline & & $M$ & $S D$ & $M$ & $S D$ & $M$ & $S D$ \\
\hline \multicolumn{8}{|c|}{ 1930s crises } \\
\hline Munich (peace) & 32 & 3.57 & 6.18 & 0.25 & 0.54 & 3.32 & 6.21 \\
\hline Poland (war) & 16 & 1.43 & 1.99 & 1.96 & 2.80 & -0.53 & 3.96 \\
\hline Difference (peace - war) & & 2.14 & & -1.71 & & 3.85 & \\
\hline \multicolumn{8}{|c|}{ 1960s crises } \\
\hline Cuban Missile Crisis (peace) & 12 & 0.77 & 0.97 & 0.55 & 0.89 & 0.22 & 1.59 \\
\hline Bay of Pigs (war) & 7 & 0.05 & 0.12 & 0.61 & 1.05 & -0.56 & 1.09 \\
\hline Difference (peace - war) & & 0.72 & & -0.06 & & 0.78 & \\
\hline
\end{tabular}

${ }^{a}$ Number of positive concessions categories scored minus number of negative concessions categories scored (each per 1,000 words).

associated with positive concessions and net concessions and negatively associated with negative concessions (i.e., rejecting concessions), whereas power motive imagery shows the reverse pattern. Considering both motive imagery scores together yielded high beta regression coefficients for each of the two motives and high multiple correlations for the combined effect of the two motives. As shown in the lower parts of the table, the overall pattern is similar for both the peace and war crises. Further analyses showed that the pattern of correlation and regression coefficients is robust across the four individual crises, the countries issuing the documents, the outcome (war or peace), and the historical era. These results linking motive imagery to concessions are consistent with previous archival and laboratory studies.

\section{Concessions and Motive Imagery: Separate Concepts or Shared Method Variance?}

Overall, these results from the archival study demonstrate that the concessions measures show the predicted relationships both to actual crisis outcomes and to motive imagery. However, because motive imagery and concessions were scored from the same documents, these latter results might arguably reflect shared method variance (i.e., overlap of the two content analysis scoring systems) rather than actual relationships between two separate, independent sets of concepts.

Several comments can be made in response to such a concern. First, the manifest contents of the two scoring systems are, in fact, very distinct (cf. Tables 1 and 2). The actual scoring of documents for concessions and motives was carried out by two scorers, at two different times; each scorer was unaware of the scorings made by the other. Moreover, the magnitudes of the correlations and regression coefficients reported in Table 3, although highly significant, indicate that the two scoring systems are empirically distinct even if they are also conceptually related.

A close analysis of the documents shows that specific positive and negative concessions are phrased in a variety of ways that do not necessarily entail imagery of any particular motive (see also Winter \& Stewart, 1977, p. 51). To illustrate this point, we cite five kinds of examples (motive images are underlined, whereas passages scored for concessions are in small capitals).

1. Sometimes, to be sure, motive images and positive or negative concessions seem intrinsically connected, as in this threat by President Kennedy (J. Kennedy, 1961) to Soviet Premier Khrushchev during the April 1961 Bay of Pigs crisis:

In the event of any military intervention [Power image] by outside force we will immediately HONOR OUR OBLIGATIONS UNDER THE INTERAMERICAN SYSTEM TO PROTECT THIS HEMISPHERE AGAINST EXTERNAL AGGRESSION. (Kennedy, 1961, p. 286) [negative concession: escalation-reciprocal; would also be Power if this sentence had not already been scored for Power motive imagery]

Table 4

Correlations and Standardized Regression Coefficients of Concessions Scores With Motive Imagery in Crisis Documents

\begin{tabular}{|c|c|c|c|c|}
\hline \multirow{3}{*}{$\begin{array}{l}\text { Crisis type and } \\
\text { concessions scores }\end{array}$} & \multicolumn{4}{|c|}{ Correlation with } \\
\hline & \multicolumn{2}{|c|}{$\begin{array}{l}\text { Affiliation } \\
\text { motivation }\end{array}$} & \multicolumn{2}{|c|}{$\begin{array}{c}\text { Power } \\
\text { motivation }\end{array}$} \\
\hline & $r$ & $\beta$ & $r$ & $\beta$ \\
\hline \multicolumn{5}{|c|}{ All crises $(N=67)$} \\
\hline $\begin{array}{l}\text { Positive concessions } \\
\text { Negative concessions } \\
\text { Net concessions }\end{array}$ & $\begin{array}{r}.19 \\
-.16 \\
.23 \dagger\end{array}$ & $\begin{array}{l}.50^{* * *} \\
-.31 * \\
.55^{* * *}\end{array}$ & $\begin{array}{l}-.22 \dagger \\
.07 \\
-.22 \dagger\end{array}$ & $\begin{array}{l}-.52^{* * *} \\
.25 \dagger \\
-.55^{* * *}\end{array}$ \\
\hline \multicolumn{5}{|c|}{ Peace crises $(n=44)$} \\
\hline $\begin{array}{l}\text { Positive concessions } \\
\text { Negative concessions } \\
\text { Net concessions }\end{array}$ & $\begin{array}{r}.18 \\
-.16 \\
.20 \\
\end{array}$ & $\begin{array}{c}.54^{* *} \\
-.26 \\
.56^{* *}\end{array}$ & $\begin{array}{l}-.23 \\
-.00 \\
-.22 \\
\end{array}$ & $\begin{array}{c}-.56^{* *} \\
.16 \\
-.57^{* *}\end{array}$ \\
\hline \multicolumn{5}{|c|}{ War crises $(n=23)$} \\
\hline $\begin{array}{l}\text { Positive concessions } \\
\text { Negative concessions } \\
\text { Net concessions }\end{array}$ & $\begin{array}{r}-.05 \\
-.27 \\
.18\end{array}$ & $\begin{array}{c}.13 \\
-.46 \dagger \\
.41 \dagger\end{array}$ & $\begin{array}{r}-.33 \\
.19 \\
-.32\end{array}$ & $\begin{array}{r}-.38 \\
.40 \dagger \\
-.50^{*}\end{array}$ \\
\hline
\end{tabular}

$\dagger p<.10 . * p<.05 . \quad * * p<.01 . \quad * * * p<.001$. 
2. Often, however, positive or negative concessions occur without any motive imagery. Here are two examples from the diplomatic messages exchanged by German Foreign Minister Ribbentrop and British Foreign Secretary Halifax during the 1938 Munich crisis:

It goes without saying that WE CANNOT ALLOW OURSELVES TO ENTER UPON ANY DISCUSSION about internal military measures. (Woodward \& Butler, 1949-1954, Vol. 2, pp. 127-129) [Negative concession: rejecting process]

His Majesty's Secretary of State for Foreign Affairs has instructed me to TRANSMIT TO THE FüHRER AND REICH CHANCELLOR THE ENCLOSED PLAN WHICH REPRESENTS A REASONABLE SCHEME FOR THE CESSION OF THE SUDETEN GERMAN AREA TO GERMANY, as accepted in principle by the Czech Government. (U.S. Department of State, 1949, pp. 986988) [Positive: de-escalation-unilateral]

Another example of concessions without motive imagery is from Khrushchev's October 27, 1962, letter to President Kennedy during the Cuban Missile Crisis:

I therefore make this proposal: WE ARE WILLING TO REMOVE FROM CUBA THE MEANS WHICH YOU REGARD AS OFFENSIVE. WE ARE WILLING TO CARRY THIS OUT AND TO MAKE THIS PLEDGE IN THE UNITED NATIONS. YOUR REPRESENTATIVE WILL MAKE A DECLARATION TO THE EFFECT THAT THE UNITED STATES, FOR ITS PART, CONSIDERING THE UNEASINESS AND ANXIETY OF THE SOVIET STATE, WILl REMOVE ITS aNALOGOUS MEANS FROM TURKEY. (U.S. Department of State, 1973, p. 648) [Positive: de-escalation-reciprocal]

3. Conversely, many motive images occur in the absence of positive or negative concessions, as in this passage from the same Khrushchev letter:

I have already said that our people, our Government, and I personally, as Chairman of the Council of Ministers, are concerned solely with having our country develop [Achievement image] and occupy a worthy place among all peoples of the world [Power image] in economic competition, in the development of culture and the arts, and in raising the living standard [Achievement image] of the people. This is the most noble and necessary field for competition, and both the victor and the vanquished [Power image] will derive only benefit from it. because it means peace and an increase in the means by which man lives and finds enjoyment [Affiliation image].

4. Sometimes, motive and concession occur in close proximity, but the motive is an antecedent to the concession, as in another message from Halifax to Ribbentrop during the Munich crisis:

His Majesty's Government are so greatly disturbed by the signs of deterioration in the atmosphere [Affiliation image-concern at disruption of a relationship] surrounding the negotiations at Prague and by the seriousness of the consequences of any other than a peaceful solution that they feel compelled to APPROACH THE GERMAN GOVERNMENT AND TO ASK FOR THEIR COOPERATION in averting any such calamitous termination to the discussion. (Woodward \& Butler, 1949-1954, Vol. 2, pp. 277-278) [Positive concession: process; would also be Affiliation if this sentence had not already been scored]

5. Finally, statements scored for concessions can be embedded in a series of different motive images, as in this German rejection of a British ultimatum at the beginning of World War II:
The German people, however, above all do not intend to allow themselves to be ill-treated by Poles [Power imagery]. The German Government therefore REJECT THE ATTEMPTS TO FORCE GERMANY, BY MEANS OF A DEMAND [Negative concession: Rejecting a previously offered proposal; would also be Power if previous sentence had not already been scored] having the character of an ultimatum, to recall its forces which are lined up for the defence of the Reich, and thereby to accept the old unrest and the old injustice. The threat that, failing this, they will fight Germany in the war [Power image], corresponds to the intention proclaimed for years past by numerous British politicians. The German Government and the German people had assured the English people countless times how much they desire an understanding, indeed close friendship, with them [Affiliation image]. If the British Government hitherto always refused these offers and now answers them with an open threat of war [Power image], it is not the fault of the German people. (Woodward and Butler, 1949-1954, Vol. 7, pp. 539-541)

On the basis of all these considerations, therefore, we believe that the concessions and motive imagery scoring systems are conceptually distinct and that their empirical relationship is not simply an artifact of shared method variance (i.e., content overlap of the two systems).

\section{Sequential Pattern of Concessions in Crises}

The Munich and Poland crises showed interesting differences in the sequential pattern of positive and negative concessions categories, although they are hardly a representative sample of all crises. (The two Cuban-related crises were too brief to permit any sequential analysis.) During the peacefully resolved Munich crisis, procedural categories scored very high in the middle and toward the end, preceded in both cases by mention of mediation. Most of the de-escalation responses occurred only at the end. In the Poland crisis, which escalated to war, procedural responses were lower overall but distributed through the early and middle stages of the crisis. De-escalation responses occurred only during the middle stages, whereas escalation as high both at the beginning and end of the crisis. Further archival and experimental studies could determine whether these contrasting patterns were typical of peacefully resolved and escalating crises.

\section{Study 2: Experimental Study of the Antecedents and Associated Behaviors of Concessions}

In the second study, we designed a laboratory experiment to explore the situational antecedents of concessions, as well as the relationship of concessions that are made in verbal exchanges to other important associated behaviors, such as people's policy choices and their implicit images about the negotiation process. The experimental procedure recapitulated, in a laboratory setting, some of the important elements of the Cuban Missile Crisis. Participants were first given different forms of a letter from Soviet Premier Nikita S. Khrushchev to U.S. President John F. Kennedy. After reading Khrushchev's letter, participants were asked to prepare a draft response for Kennedy's signature. These responses were scored for concessions and for power and affiliation motivation. Then, participants were asked to evaluate specific options for United States action and to respond to several questions.

By varying certain features of the Khrushchev letter, it was possible to determine the antecedents of (a) the level of conces- 
sions in participants' responses, (b) the motive imagery levels in participants' responses, and (c) the aggressiveness of their action choices.

\section{Method}

Participants. Participants consisted of 118 students (61 women, 56 men, and 1 who did not report gender) who were enrolled in an introductory psychology class at the University of Michigan. They participated to fulfill a course research participation requirement. Participants were tested in small groups of 20 to 30 people by the first author. Average age was 18.71 years $(S D=0.88)$. Fifty percent were first-year students, $35 \%$ were sophomores, and $15 \%$ were more advanced students. Sixty-four percent were Caucasian, $11 \%$ Asian American, $8 \%$ African American, and $17 \%$ "other" or not indicated.

Procedure. The basic procedure used in Study 2 was adapted from a study by Peterson et al. (1994, Study 1). Participants were instructed as follows:

In this experiment, you are first asked to read a brief summary of an international crisis - the Cuban Missile Crisis of October 1962along with some historical materials from that crisis. After reading this material, you will be asked to write a response on the notepaper [provided].... After you have finished writing your response, please complete the additional questionnaires.

Participants were then given a one-page "Historical Background to the Cuban Missile Crisis of October 1962." Then, they read an abbreviated version of the letter written by Soviet Premier Nikita Khrushchev to U.S. President John F. Kennedy on October 26, at the climax of the crisis. In this letter, Khrushchev reviewed the actions and perceptions of each side and then cautioned the following:

Mr. President, you and I should not now pull on the ends of the rope in which you have tied a knot of war, because the harder you and I pull, the tighter this knot will become. And a time may come when this knot is tied so tight that the person who tied it is no longer capable of untying it, and then the knot will have to be cut. What that would mean I need not explain to you, because you yourself understand perfectly what dread forces our two countries possess.

Calling on each side to show "statesmanlike wisdom," Khrushchev proposed the compromise that became the basis for the ultimate settlement of the crisis (The complete original letter is reproduced in U.S. Department of State, 1973; the basic version used in the present study is from Peterson et al., 1994, pp. $742-744$.)

After reading the letter, participants were asked to perform the following task:

Imagine that you are really in the middle of a major historical crisis. Please imagine that you are an advisor to President Kennedy. The letter you have read has just come in and the President has asked you to draft a reply to send to Khrushchev.

Participants were given a sheet of lined paper, headed "The White House," with the date of October 27, 1962, and an inside address to "Chairman Nikita S. Khrushchev, The Kremlin, Moscow, U.S.S.R." entered at the top and "John F. Kennedy, President of the United States" at the bottom. Participants were allowed about $20 \mathrm{~min}$ to write their responses.

After finishing their draft response letters, participants were asked to indicate their preferred policies for dealing with the crisis by indicating their agreement (on a 9-point Likert scale, ranging from 1 (strongly do not favor) to 9 (strongly favor), with the following seven possible U.S. actions (taken from Peterson et al., 1994):
1. Ignore Khrushchev; bomb the missile bases and launch a full-scale U.S. invasion to remove all offensive weapons and overthrow the Castro regime.

2. Ignore Khrushchev, and bomb the missile bases.

3. Ignore Khrushchev, and tighten the U.S. blockade to include oil.

4. Ignore Khrushchev; leave the U.S. blockade as it is, and wait.

5. Leave the U.S. blockade as it is, but offer to negotiate with Khrushchev on the basis of his proposals.

6. Call off the blockade, and offer to negotiate with Khrushchev on the basis of his proposals.

7. Accept his proposals as they stand, and call off the blockade.

Two summary scores were calculated from the overall pattern of participants' policy choices. Because the seven items, arranged in the above order, form an approximate Thurstone scale, ${ }^{5}$ it was possible to calculate an "overall peacefulness of policy choices" score by multiplying ratings of the seven responses by $-3,-2,-1,0,1,2$, and 3 , respectively, and then calculating the mean (Thurstone \& Chave, 1929, p. 64). However, from both theoretical and practical points of view, another important summary measure is participants' average endorsement of Policy Choices 5, 6, and 7, all of which involve negotiation and, thus, de-escalation. This is described as the "average endorsement of negotiation choices."

Using semantic differential methods (Osgood, Suci, \& Tannenbaum, 1957), participants then rated the following five concepts on 13 seven-point bipolar adjective scales: NikiTA KhrushCHEV, John F. KENNEDy, Your RePly to KhrushCHEV's LetTer, AN IDEAL LEADER, and COMPROMISE. ${ }^{6}$ According to semantic differential theory, these adjective scales yield scores for the three major dimensions of connotative meaning: evaluation (good-bad), potency (strong-weak), and activity (active-passive). Finally, participants were asked their gender, ethnicity, year in college, and (on 9-point scales) "How interested in international relations are you?" (anchoring points of 1 [extremely disinterested] to 9 [extremely interested]) and "Before this experiment, how familiar were you with the Cuban Missile Crisis?" (anchoring points of 1 [extremely unfamiliar] to 9 [extremely familiar]). The experimenter also noted the time of day of each experimental session.

Khrushchev letter versions. The abbreviated Khrushchev letter had been previously been coded for power and affiliation motivation by an expert scorer, according to Winter's (1991) manual (see Peterson et al., 1994). For the present study, four different versions of this abbreviated letter were created, involving different combinations of motivation and concession. Appendix B presents these four variations of the Khrushchev letter. In two versions of the letter (the power motivation conditions), all 9 sentences with affiliation imagery were removed and all 14 sentences with power motive imagery were retained. In the other two versions (the affiliation motivation conditions), the 14 power images were removed and the 9 affiliation images retained. These two motivation conditions were crossed by two concession conditions. In the "explicit concession" conditions, Khrushchev's compromise offer was explicitly quoted, as follows:

I propose: We, for our part, will declare that our ships bound for Cuba are not carrying any armaments. You will declare that the United States will not invade Cuba with its troops and will not support any other forces which might intend to invade Cuba.

(In terms of the concessions scoring system introduced in this article, this passage would be scored for positive concession Category 3, "De-escala-

${ }^{5}$ That is, the correlations of each item with adjacent items are positive and higher than the correlations with all other items.

${ }^{6}$ The following 7-point adjective scales were used, in this order: strongweak, peaceful-ferocious, fast-slow, bad-good, small-large, staticdynamic, cruel-kind, sharp-dull, unpleasant-pleasant, unfair-fair, dishonest-honest, brave-cowardly, passive-active, and gentle-violent. 
Table 5

Correlations of Concessions Measures With Policy Choices

\begin{tabular}{|c|c|c|c|}
\hline \multirow[b]{2}{*}{ Agreement with policy choice } & \multicolumn{3}{|c|}{ Correlation with } \\
\hline & $\begin{array}{l}\text { Positive } \\
\text { concessions }\end{array}$ & $\begin{array}{l}\text { Negative } \\
\text { concessions }\end{array}$ & $\begin{array}{c}\text { Net } \\
\text { concessions }\end{array}$ \\
\hline \multicolumn{4}{|l|}{ Escalation responses } \\
\hline Bomb missile bases and invade Cuba & -.08 & .03 & -.07 \\
\hline Bomb missile bases & -.09 & .13 & -.14 \\
\hline Tighten blockade to include oil & $-.25 * *$ & $.21 *$ & $-.30 * * *$ \\
\hline \multicolumn{4}{|l|}{ Neutral response } \\
\hline Keep blockade and wait & -.11 & .01 & -.08 \\
\hline \multicolumn{4}{|l|}{ Negotiation responses } \\
\hline Keep blockade and offer to negotiate & $.18 \dagger$ & $-.33 * * *$ & $.34 * * *$ \\
\hline End blockade and offer to negotiate & $.19^{*}$ & -.09 & $.18 \dagger$ \\
\hline End blockade and accept Khrushchev's offer & $.25^{* *}$ & $-.18 *$ & $.28 * *$ \\
\hline \multicolumn{4}{|l|}{ Summary measures } \\
\hline Overall peacefulness of policy choices & $.24 * *$ & $-.20 *$ & $.28 * *$ \\
\hline Average endorsement of negotiation choices & $.27 * *$ & $-.27 * *$ & $.35^{* * *}$ \\
\hline
\end{tabular}

$\dagger p<.10 . \quad * p<.05 . \quad * * p<.01 . \quad * * * p<.001$.

tion: Reciprocal"). In contrast, the no-concession conditions omitted this passage, which left the excerpt of Khrushchev's letter containing only threats, warnings, and a nonspecific call for "statesmanlike wisdom." Some of these versions might seem incongruous: for example, a letter with many power images that offered a concession, or a letter full of affiliation imagery without an explicit concession. However, we believe that each of the four versions was plausible as a single, free-standing communication. (Readers can form their own judgment on this point by consulting Appendix B.)

The four different versions of the abbreviated Khrushchev letter were randomly mixed together by stacking the versions in random order, thus creating a $2 \times 2$ factorial design for analyzing the effects of the motive imagery (affiliation vs. power) and concession (explicit concession vs. no concession) in Khrushchev's letter on several variables: (a) the concessions and motive imagery in the responses participants drafted for the president, (b) participants' policy choices, and (c) participants' implicit images of various aspects of the negotiation process. All four conditions (i.e., Khrushchev letter versions) thus occurred in each of the experimental sessions.

Scoring of response letters. All response letters were scored for motive imagery by an expert scorer, who had previously demonstrated high reliability (category agreement $\geq .85$ ) on materials precoded by expert scorers. Concessions were scored by the first author, who was blind to the experimental condition and all other information about the participants and their responses. Motive scores were expressed in the usual way, as images per 1,000 words. The brevity of the response letters (range $=27-229$ words, $M d n=129$ words), however, meant that most concession categories were scored only once if at all. (Ninety eight percent of all positive concessions scores and $93 \%$ of all negative concessions scores were either 0 or 1.) Adjusting raw scores for length, as was done with the much longer diplomatic documents used in Study 1, would actually introduce substantial distortion. For purposes of the present study, the important point was whether, in response to different versions of the Khrushchev letter, the letters contained any concession; therefore, concession scores were not adjusted for length of response. ${ }^{7}$ The Pearson correlations with these measures, therefore, approach the point-biserial correlations that would be obtained by using the collapsed presence/absence scores.

Plan of analysis and hypotheses. Study 2 was designed to explore, in an experimental setting, the antecedents and associated consequences of making concessions (i.e., of the concessions scores in participants' letters). We were interested in three basic questions: (a) Would the relationships, observed in the archival study, between affiliation motivation and positive concessions, and power motivation and negative concessions, replicate at the individual level? To answer this question, we correlated the motive scores and the concessions scores in participants' response letters. (b) What variables in the negotiation process might induce concessions? We hypothesized that the presence of an explicit (positive) concession in Khrushchev's letter would cause participants to reciprocate with an explicit positive concession in their response. Further, we expected that the affiliation motivation version of the Khrushchev letter would be more likely to elicit concessions in participants' responses. (c) Finally, we were interested in exploring the relationship among both concessions and motivation in participants' response letters and their explicit policy choices, as well as the connotative meanings reflected in their images of the major actors in the crisis (Kennedy, Khrushchev), the concept of ideal leader, their own responses, and the concept of concessions.

\section{Results}

Validation of the concessions measures. The first task was to extend the validity of the concessions measures, established by the archival research of Study 1, to the present experimental study. In other words, did those people who wrote responses to Khrushchev that scored higher in concessions also choose less aggressive policies? Table 5 presents the relationships between positive and negative concessions and endorsements of different policy options. In general, people scoring high in positive concessions and net concessions tended to endorse specific policy choices that involved negotiation rather than escalation and score higher on both the "overall peaceable" and the negotiation summary scores. People scoring high in negative concessions, in contrast, tended to endorse at least moderate escalation (tightening the blockade to include oil, higher overall aggressiveness of policy choices) rather than any kind of negotiation. Thus the content of students' open-

\footnotetext{
${ }^{7}$ Collapsing the positive and negative concessions scores to simple presence-absence measures produced essentially the same results. For ease of presentation, however, we present the results using continuous scores.
} 
Table 6

Descriptive Statistics From Experimental Study of Concessions

\begin{tabular}{|c|c|c|c|c|c|c|c|c|c|c|c|c|c|c|}
\hline \multirow[b]{3}{*}{ Experimental condition } & \multicolumn{10}{|c|}{ Response to Khrushchev letter } & \multicolumn{4}{|c|}{ Summary policy choices } \\
\hline & \multicolumn{2}{|c|}{$\begin{array}{l}\text { Positive } \\
\text { concessions }\end{array}$} & \multicolumn{2}{|c|}{$\begin{array}{l}\text { Negative } \\
\text { concessions }\end{array}$} & \multicolumn{2}{|c|}{$\begin{array}{c}\text { Net } \\
\text { concessions }\end{array}$} & \multicolumn{2}{|c|}{$\begin{array}{l}\text { Affiliation } \\
\text { motivation }\end{array}$} & \multicolumn{2}{|c|}{$\begin{array}{l}\text { Power } \\
\text { motivation }\end{array}$} & \multicolumn{2}{|c|}{$\begin{array}{c}\text { Overall } \\
\text { peacefulness }\end{array}$} & \multicolumn{2}{|c|}{$\begin{array}{l}\text { Negotiation } \\
\text { choices }\end{array}$} \\
\hline & $M$ & $S D$ & $M$ & $S D$ & $M$ & $S D$ & $M$ & $S D$ & $M$ & $S D$ & $M$ & $S D$ & $M$ & $S D$ \\
\hline $\begin{array}{l}\text { Affiliation, explicit } \\
\text { concession }(n=30)\end{array}$ & 0.47 & 0.51 & 0.30 & 0.47 & 0.17 & 0.75 & 7.23 & 8.00 & 14.61 & 9.23 & 1.40 & 18.83 & 4.42 & 1.56 \\
\hline $\begin{array}{l}\text { Affiliation, no concessions } \\
\qquad(n=30)\end{array}$ & 0.28 & 0.45 & 0.38 & 0.47 & -0.10 & 0.77 & 6.75 & 8.86 & 14.10 & 10.00 & 1.14 & 16.26 & 3.99 & 1.57 \\
\hline $\begin{array}{l}\text { Power, explicit concessions } \\
\qquad(n=28)\end{array}$ & 0.54 & 0.64 & 0.46 & 0.64 & 0.07 & 0.94 & 2.50 & 5.81 & 22.35 & 18.98 & 6.07 & 16.09 & 4.91 & 1.37 \\
\hline $\begin{array}{l}\text { Power, no concessions } \\
\quad(n=30)\end{array}$ & 0.23 & 0.43 & 0.60 & 0.77 & -0.37 & 0.96 & 2.85 & 4.81 & 22.01 & 12.13 & -0.13 & 16.63 & 4.21 & 1.52 \\
\hline $\begin{array}{l}\text { All conditions combined } \\
(N=117)\end{array}$ & 0.38 & 0.52 & 0.44 & 0.62 & -0.06 & 0.87 & 4.85 & 7.30 & 18.24 & 13.47 & 2.06 & 16.95 & 4.38 & 1.53 \\
\hline
\end{tabular}

ended negotiation responses was related to their actual policy choices.

Motives and concessions. In participants' response letters, motive imagery scores were related to concessions in the same ways as in Study 1: Affiliation motive imagery was positively related to positive concessions $(r=.22, N=118, p<.05)$ and negatively related to negative concessions $(r=-.28, p<.01)$, whereas power motive imagery was negatively related to positive concessions $(r=-.16, p<.10)$ and positively related to negative concessions $(r=.37, p<.001) .^{8}$

Effects of experimental conditions on concessions and motivation expressed in participants' responses. A preliminary analysis showed no pattern of significant relationships among the dependent variables and the demographic variables (ethnicity, year in college), interest in international relations, or previous knowledge of the Cuban Missile Crisis. ${ }^{9}$ (The effects of gender will be discussed below.) Table 6 , therefore, presents descriptive statistics on the major variables of Study 2 for each of the four separate experimental conditions defined by the four versions of the Khrushchev letter as well as for the entire combined sample.

The effects of the experimental conditions were tested with three-way analyses of variance for the dependent variables based on participants' responses to Khrushchev and their policy choices, with the Khrushchev letter experimental conditions (variables of explicit concession and affiliation versus power motivation) and participants' gender as main effects. Whether the Khrushchev letter contained an explicit concession had a main effect on whether participants in their response offered a positive concession, $F(1,109)=7.17, p=.009$, and offered more net concessions, $F(1,109)=4.25, p=.042$, though it was unrelated to participants' negative concessions. The same reciprocal pattern was observed for the motive imagery content of the Khrushchev letter. Participants receiving the affiliation version responded with higher affiliation, $F(1,109)=12.24, p<.001$, and lower power, $F(1,109)=10.54, p=.002$, than did those receiving the power version. (That power was greater than affiliation in all conditions was probably due to the "pulling power" or motive-arousal effects of the experimental situation.) There was a near-significant trend for the Khrushchev letter version that offered an explicit concession to elicit a higher average endorsement of negotiation choices,
$F(1,109)=3.08, p=.082$. There were no significant interactions of the two Khrushchev letter experimental conditions (Motivation Condition $\times$ Concession Condition).

Gender showed only three significant or near-significant main effects: For positive concessions, women were higher, $F(1$, $109)=3.76, p=.055$; for peacefulness of policy choices, women scored higher, $F(1,109)=2.97, p=.087$; and for negotiation policy choices, women scored higher, $F(1,109)=4.72, p=.032$. These effects are consistent with other evidence showing that, under some circumstances at least, women tend to show lower levels of certain kinds of aggressive behaviors than do men (Geen, 1998, pp. 330-332). There were no gender differences in either motive imagery score. There was one significant two-way interaction involving gender: women responded with higher power motive imagery (though not more aggressive responses) when Khrushchev's letter included an explicit concession, whereas men showed the opposite pattern, $F(1,109)=8.00, p=.006$. Perhaps in a simulated international conflict (until recently, at least, a stereotypically male situation), these women felt pressure to embellish their response to a "dove" (Khrushchev's concession) with their own imagery of the "hawk" (power motive). Finally, there was one near-significant three-way interaction: Inspection of means showed that in the two mildly incongruous conditions (Khrushchev's letter if either high affiliation with no concessions or high power with concessions), women had higher average endorsement of negotiation choices than did men, $F(1$, $109)=3.71, p=.057$. Perhaps in such situations of mild incongruity between cues about the intentions of the other side, women

\footnotetext{
${ }^{8}$ The discussion of possible method overlap between the concessions and motive imagery methods, in connection with Study 1, applies to Study 2 as well.

${ }^{9}$ Time of day was related to policy choices, with afternoon participants making more aggressive choices than morning participants. It is not possible to determine whether this reflects a true effect of time or differences among participants who signed up for different times. Because time of day was not significantly related to either of the experimental conditions, the concessions or motive scores in participants' responses, or any other demograpnic variable, this effect was ignored in subsequent analyses.
} 

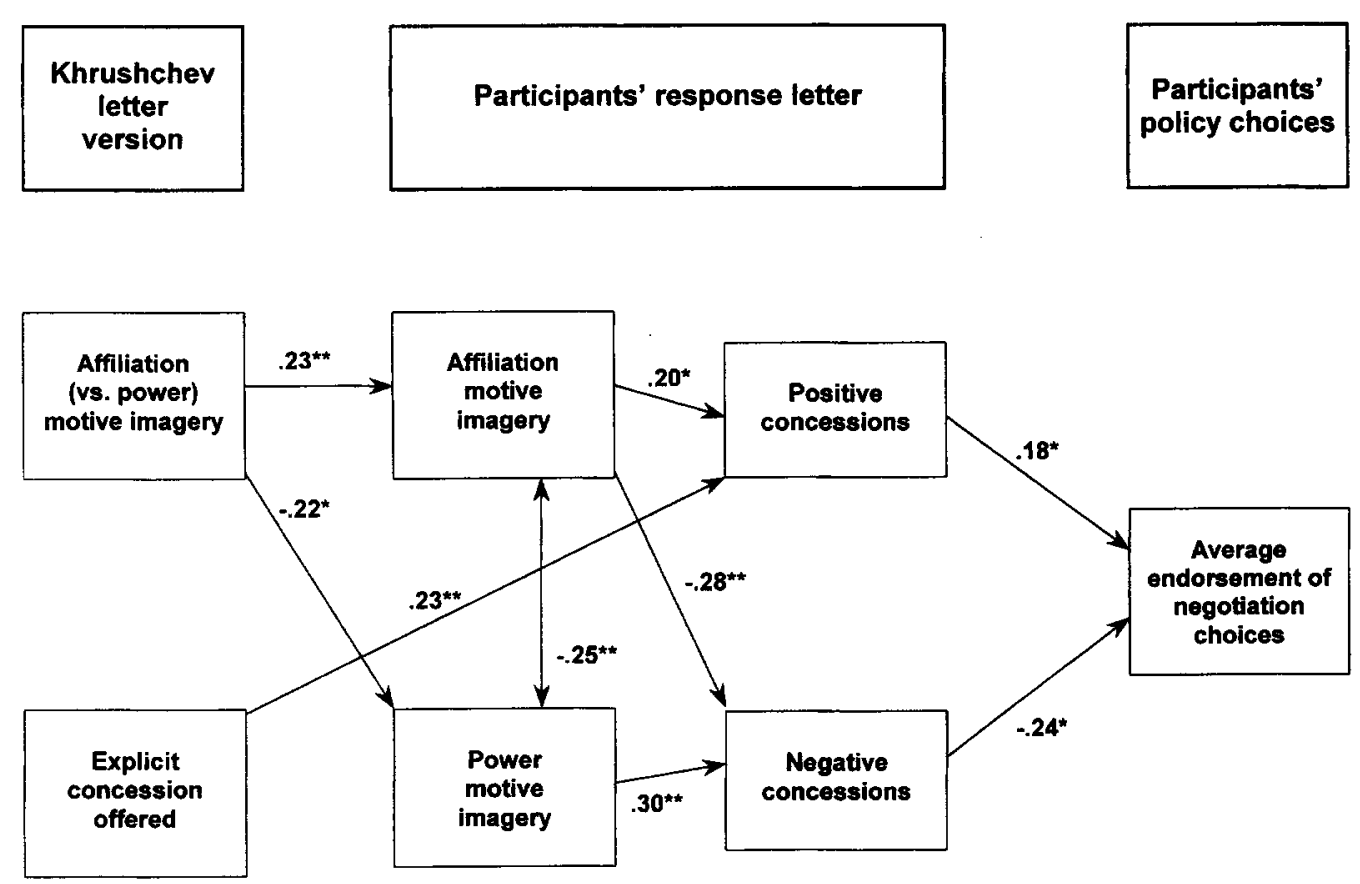

Figure 1. Post hoc path analysis of variables from Study $2 .{ }^{*} p<.05 . \quad * * p<.01$.

tend to respond to whichever cue (explicit concession or affiliation motive imagery) suggests de-escalation.

Interrelationships of experimental conditions, participants' responses, and policy choices. As a way of drawing together the different results of Study 2, Figure 1 presents the results of a descriptive path analysis showing all significant relationships between experimental condition and response variables to the average endorsement of negotiation choices (i.e., the average endorsement of the three policy choices involving negotiation). The causal ordering reflected in this figure assumes that the two experimental conditions involving the Khrushchev letter precede the characteristics of the participants' response letter and that, within the letter, motives precede concessions. These assumptions are certainly debatable; however, the intention of the figure is to give a coherent overall description of our results rather than to test a single specific causal model. Obviously this is a post hoc model that needs further testing in future replications. As suggested by the figure, the explicit concession-related content of a received communication directly affects the tendency to offer explicit concessions in response. The motive imagery of the received communication directly affects the motive imagery of the response; the response motive imagery, in turn, affects explicit concessions offered in the response. This suggests, as a potential general principle, that the motive imagery of communications-involving affective tone more than explicit content-has effects on concessions that are indirect or mediated by the arousal of motive imagery of responses. ${ }^{10}$

Making concessions and the image of compromise. The semantic differential measures connotative meanings along three dimensions of evaluation, potency, and activity. In Study 2, the major significant results involved participants' evaluation and potency ratings of COMPROMISE and YouR REPLY TO KHRUSHCHEV's
LETTER. As shown in Table 7, participants who made positive concessions tended to view their own response as higher in evaluation and lower in potency, whereas participants who made negative concessions showed the reverse pattern. Interestingly enough, people's tendency to make concessions was not related to the perceived potency of concession making itself. Gender was related to participants' images of compromise and their own responses. Women tended to view COMPROMISE as both better and stronger while rating their own responses as weaker. (Recall that women made more positive concessions than did men.)

Summary of experimental results. The explicit offering of a concession or lack thereof by the Khrushchev letter had a reciprocal effect on whether participants offered a positive concession in response. The motive imagery in the Khrushchev letter also had a reciprocal effect on motive imagery levels in participants' responses: The affiliation version elicited higher affiliation and lower power than did the power version. In other words, received concessions primed concessions offered in response, and received motive imagery primed response motive imagery. In this experiment, there were no significant cross-primes; that is, concessions did not directly prime motive imagery, or vice versa.

The motive imagery results of Study 2 replicate the archival findings of the archival Study 1 reported previously. Making positive concessions is positively related to affiliation motivation and negatively related to power motivation, whereas making negative concessions shows the reverse pattern. The pattern of con-

\footnotetext{
${ }^{10}$ The concept of motive, as used in this research, includes features of dispositional stability and situational arousability, as discussed by Winter (1996, pp. 33-34).
} 
Table 7

Correlations of Concessions Measures With

Images of Concession

\begin{tabular}{lccc}
\hline & \multicolumn{3}{c}{ Correlation with } \\
\cline { 2 - 4 } & $\begin{array}{c}\text { Positive } \\
\text { concessions }\end{array}$ & $\begin{array}{c}\text { Negative } \\
\text { concessions }\end{array}$ & $\begin{array}{c}\text { Female } \\
\text { gender }\end{array}$ \\
\hline Semantic differential variable & .09 & $-.20^{*}$ & $.20^{*}$ \\
COMPROMISE-evaluation & .00 & -.02 & $.34 * * *$ \\
COMPROMISE-potency & $.30^{* * *}$ & $-.17 \dagger$ & -.09 \\
$\begin{array}{l}\text { YOUR RESPONSE TO KHRUSHCHEV's } \\
\text { LETTER-evaluation }\end{array}$ & & $.23^{*}$ & $-.25^{* *}$ \\
$\begin{array}{l}\text { YOUR RESPONSE TO KHRUSHCHEV's } \\
\text { LETTER-potency }\end{array}$ & $-.20^{*}$ & & \\
\hline$t p<.10 . * p<.05 . \quad * * p<.01$. & $* * * p<.001$. &
\end{tabular}

cession making in participants' response letters was related to their endorsement of policy choices involving negotiation.

One might wonder whether students' knowledge of how the Cuban Missile Crisis actually ended (presuming that they actually knew) could somehow bias their responses and thus affect the results. This is an unavoidable problem for experiments that use actual crises rather than laboratory simulations (except on rare occasions such as the fall of 1990, when the Gulf Crisis was ongoing and the ultimate result was unknown), but it is difficult to determine the effects of such knowledge. On the one hand, one could argue that knowing the crisis ended peacefully would make participants more reckless in their responses; on the other hand, the fact that the Cold War had long since ended might make them more conciliatory. In any case, however, any general effect for participants to imitate Kennedy's decisions and actions in 1962 should tend to wipe out, rather than create, the effects observed here. Finally, as discussed above, we found that students' selfreported knowledge of the crisis was unrelated to any of their responses.

\section{Discussion}

\section{Main Findings}

Taken together, the results of these two studies extend our knowledge of how conflicts may be resolved through compromise, because they illuminate some important motivational and situational dynamics of making (or rejecting) concessions. Both in archival and laboratory settings, the affiliation motive is associated with positive concessions; power motivation, in contrast, predicts negative concessions or rejecting concessions offered by the other side. In the laboratory study, the concession-related content of a message elicited or primed concessions in response, and the motivational tone of the message primed motive imagery in response. Response motive imagery, in turn, was related to offering concessions and to endorsing policy choices involving negotiation. These are important effects, because in both archival and experimental studies, concessions (and their associated motive imagery) have been shown to be related to policy and ultimate outcomes of war versus peace. Thus the present studies increase the precision of terms such as cooperative and competitive negotiating orientations, which have been used to describe individual state and trait differences in negotiation style.
These findings are consistent with previous studies of international negotiations relating concessions to rhetoric (Beriker \& Druckman, 1991; Druckman, 1986; Druckman \& Harris, 1990; Stoll \& McAndrew, 1986) and demonstrating matching (or "titfor-tat") effects during the course of negotiation (Carnevale \& Pruitt, 1992).

\section{System for Scoring Concessions}

Taken together, the two studies provided both archival and experimental validation for the system for scoring and measuring concessions. Because the positive and negative concessions measures showed the predicted relationship to crisis outcome (archival study) and policy choices (experimental study), they can be seen as reflecting critical elements of the compromise (or escalation) process.

\section{Psychological Model of the Concession-Compromise Process}

Our results suggest some aspects of a general model of the compromise process. The tendencies to make positive concessions, and not to make negative concessions, seem to be critical determinants of whether a conflict will be peacefully resolved or escalate to war. The present research suggests that offering concessions, in turn, is a function of three factors: (a) people's dispositional motive levels (i.e., their balance between power and affiliation motivation), (b) the balance of power and affiliation motivation in messages they receive during the negotiation process (which appear to act as motive-arousal experiences; see Winter, 1998), and (c) whether explicit concessions are offered to them in messages they receive during negotiation.

Of course motives are only one of the psychological elements that contribute to productive negotiations that can turn crises from escalation to peaceful resolution. Other variables, such as the tendency to be hostile and punitive toward out-groups (reflected in authoritarianism and social dominance orientation), cognitive complexity, and the many individual and structural characteristics reviewed at the beginning of this article also play important roles in negotiation outcomes.

\section{A Concluding Cautionary Note From History}

Concessions are often essential to successful negotiation and the maintenance of peace; however, concessions and compromise may not always be strategically effective or even morally "good." Thus, most historians regard the British concessions and compromises embodied in the 1938 Munich agreements with Hitler-described by British Prime Minister Neville Chamberlain as bringing "peace with honour ... peace for our time" (1939, p. 200)—as a cowardly and (ultimately) ineffective attempt to appease a brutal bully. " There may be occasions where concessions (especially if they are not reciprocated, or reciprocated only in superficial ways) are

\footnotetext{
"Some historians, however, have suggested that by postponing an inevitable war, the Munich agreements did give Britain more time to rebuild its armed forces, though it is doubtful that this was Chamberlain's intention in making them (see P. Kennedy, 1986).
} 
neither virtuous nor prudent. Psychological analysis can only be an aid to political wisdom, not a substitute for it.

\section{References}

Altemeyer, B. (1996). The authoritarian specter. Cambridge, MA: Harvard University Press.

Beriker, N., \& Druckman, D. (1991). Models of responsiveness: The Lausanne peace negotiations (1922-1923). Journal of Social Psychology, 131, 297-300.

Boyle, F. A. (1985). World politics and international law. Durham, NC: Duke University Press.

Carnevale, P. J., \& Pruitt, D. G. (1992). Negotiation and mediation. Annual Review of Psychology, 43, 531-582.

Chamberlain, N. (1939). In search of peace. New York: Putnam's Sons.

Cicero, M. T. (1953). Letters to his friends, (Vol. 2). Cambridge, MA: Harvard University Press.

Clifford, C. M. (1968). American relations with the Soviet Union: A report to the president by the special counsel to the president. Reprinted in A. Krock (Ed.), Memoirs: Sixty years on the firing line (Appendix A, pp. 419-482). New York: Funk \& Wagnalls. (Original work published 1946)

de Gaulle, C. (1970). Discours et messages. Vol. 4: Pour l'effort-Août 1962-Décembre 1965 [Discourses and messages. Vol. 4: For the effort-August 1962-December 1965]. Paris: Librairie Plon.

Deutsch, M. (1982). Interdependence and psychological orientation. In V. J. Derlega \& J. Grzelak (Eds.), Cooperation and helping behavior: Theories and research (pp. 15-42). New York: Academic Press.

Druckman, D. (1967). Dogmatism, prenegotiation experience, and simulated group representation as determinants of dyadic behavior in a bargaining situation. Journal of Personality and Social Psychology, 6, 279-290.

Druckman, D. (1986). Stages, turning points, and crisis: Negotiating military base rights, Spain and the United States. Journal of Conflict Resolution, 30, 327-360.

Druckman, D. (1994), Determinants of compromising behavior in negotiation: A meta-analysis. Journal of Conflict Resolution, 38, 507-556.

Druckman, D. (1997). Negotiating in the international context. In I. W. Zartman \& J. L. Rasmussen (Eds.), Peacemaking in international conflict: Methods and techniques (pp. 81-123). Washington, DC: United States Institute of Peace Press.

Druckman, D. (2000, July). Turning points in international negotiation: A comparative analysis. Paper presented at the annual meeting of the International Society of Political Psychology, Seattle, WA.

Druckman, D., \& Harris, R. (1990). Alternative models of responsiveness in international negotiation. Journal of Conflict Resolution, 34, 234252.

Etheredge, L. S. (1978). A world of men: The private sources of American foreign policy. Cambridge, MA: MIT Press.

Etzioni, A. (1967). The Kennedy experiment: Unilateral initiatives. Western Political Quarterly, 20, 361-380.

Fisher, R., \& Ury, W. (1991). Getting to yes: Negotiating agreement without giving in. New York: Penguin.

Fursenko, A., \& Naftali, T. (1997). "One hell of a gamble:" Khrushchev, Castro, and Kennedy, 1958-1964. New York: Norton.

Geen, R. R. G. (1998). Aggression and social behavior. In D. T. Gilbert, S. T. Fiske, \& G. Lindzey (Eds.), Handbook of social psychology, 4th ed. (Vol. 2, pp. 317-356). Boston: McGraw-Hill.

George, A. L. (1979). Case studies and theory development: The method of structured, focused comparison. In P. G. Lauren (Ed.), Diplomacy: New approaches in history, theory, and policy (pp. 43-68). New York: Free Press.

Gilbert, D. T., Fiske, S. T., \& Lindzey, G. (Eds.), Handbook of social psychology (4th ed.). Boston: McGraw-Hill.
Greenstein, F. I. (1987). Personality and politics: Problems of evidence, inference, and conceptualization. Princeton, NJ: Princeton University Press. (Original work published 1969)

Grzelak, J. (1994). Conflict and cooperation: Motivational bases. In G. d'Ydewalle, P. Eelen, \& P. Bertelson (Eds.), International perspectives on psychological science: Vol. 2. The state of the art (pp. 249-263). Hove, United Kingdom: Erlbaum.

Jervis, R. (1976). Perception and misperception in international politics. Princeton, NJ: Princeton University Press.

Kennedy, J. F. (1961). Public papers of the president: John Fitzgerald Kennedy 1961. Washington, DC: U.S. Government Printing Office.

Kennedy, P. (1986). Appeasement. In G. Martel (Ed.), The origins of the Second World War reconsidered: The A. J. P. Taylor debate after twenty-five years (pp. 140-161). London: Unwin Hyman.

Khong, Y. F. (1992). Analogies at war: Korea, Munich, Dien Bien Phu, and the Vietnam decisions of 1965 . Princeton, NJ: Princeton University Press.

Kornbluh, P. (Ed.). (1998). Bay of Pigs declassified: The secret CIA report on the invasion of Cuba. New York: New Press.

Kriesberg, L. (1998). Constructive conflicts: From escalation to resolution. Lanham, MD: Rowman \& Littlefield.

Kriesberg, L., \& Thorson, S. J. (1991). Timing the de-escalation of international conflicts. Syracuse, NY: Syracuse University Press.

La Couture, J. (1991). De Gaulle: The ruler 1945-1970. London: Harvill.

Langner, C. A. (1997). Concessions, affiliation motivation, and perception in archival and laboratory conflict situations. Unpublished honors thesis, University of Michigan.

Lebow, R. N. (1996). The art of bargaining. Baltimore, MD: Johns Hopkins University Press.

McClelland, D. C., Koestner, R., \& Weinberger, J. (1989). How do self-attributed and implicit motives differ? Psychological Review, 96, $690-702$.

Morgenthau, H. (1967). Politics among nations: The struggle for power and peace, 4th ed. New York: Knopf.

Morley, I. E., \& Stephenson, G. M. (1977). The social psychology of bargaining. London: Allen \& Unwin.

Morris, M. W., Larrick, R. P., \& Su, S. K. (1999). Misperceiving negotiation counterparts: When situationally determined bargaining behaviors are attributed to personality traits. Journal of Personality and Social Psychology, 77, 52-67.

Neustadt, R. E., \& May, E. R. (1986). Thinking in time: The uses of history for decision-makers. New York: Free Press.

Osgood, C. E., Suci, G. J., \& Tannenbaum, P. J. (1957). The measurement of meaning. Urbana: University of Illinois Press.

Patchen, M. (1987). Strategies for eliciting cooperation from an adversary: Laboratory and internation findings. Journal of Conflict Resolution, 31, $164-185$.

Peterson, B. E., Winter, D. G., \& Doty, R. M. (1994). Laboratory tests of a motivational-perceptual model of conflict escalation. Journal of Conflict Resolution, 38, 719-748.

Pruitt, D. G. (1983). Achieving integrative agreements in negotiation. In M. H. Bazerman \& R. J. Lewicki (Eds.), Negotiating in organizations (pp. 35-50). Beverly Hills, CA: Sage.

Pruitt, D. G. (1998). Social conflict. In D. T. Gilbert, S. T. Fiske, \& G. Lindzey (Eds.), Handbook of social psychology, 4th ed. (Vol. 2, pp. 470-503). Boston: McGraw-Hill.

Pruitt, D. G., \& Rubin, J. Z. (1986). Social conflict: Escalation, stalemate, and settlement. New York: McGraw-Hill.

Rank, O. (1914). "Um Städte werben" [Conquering cities and "conquering" women]. Internationale Zeitschrift für ärztliche Psychoanalyse, 2, $50-58$.

Rubin, J. Z. (Ed.). (1981). Dynamics of third party intervention: Kissinger in the Middle East. New York: Praeger. 
Rubin, J. Z. (1994). Models of conflict management. Journal of Social Issues, 50(1), 33-45.

Rusk, D. (1990). As I saw it. New York: Norton.

Schelling, T. C. (1963). The strategy of conflict. Cambridge, MA: Harvard University Press.

Schmookler, A. B. (1984). The parable of the tribes: The problem of power in social evolution. Berkeley and Los Angeles: University of California Press.

Schnackers, U., \& Kleinbeck, U. (1975). Machmotiv and machtthematisches Verhalten in einem Verhandlungsspiel [Power motivation and power-related behavior in a bargaining game]. Archiv für Psychologie, $127,300-319$.

Scott, J. W. (1986). Gender: A useful category of historical analysis. American Historical Review, 91, 1053-1075.

Smith, C. P. (Ed.). (1992). Motivation and personality: Handbook of thematic content analysis. New York: Cambridge University Press.

Sorenson, T. C. (1965). Kennedy. New York: Harper \& Row.

Stoll, R. J., \& McAndrew, W. (1986). Negotiating strategic arms control, 1969-1979. Journal of Conflict Resolution, 30, 315-326.

Suedfeld, P., \& Tetlock, P. (1977). Integrative complexity of communications in international crises. Journal of Conflict Resolution, 21, 169 184.

Terhune, K. W. (1968). Motives, situation, and interpersonal conflict within prisoner's dilemma. Journal of Personality and Social Psychology Monograph Supplement, 8(3, part 2).

Terhune, K. W. (1970). The effects of personality in cooperation and conflict. In P. Swingle (Ed.), The structure of conflict (pp. 193-234). New York: Academic Press.

Tetlock, P. E. (1979). Identifying victims of groupthink from public statements of decision makers. Journal of Personality and Social Psychology, 37, 1314-1324.

Thompson, L. (1990). Negotiation behavior and outcomes: Empirical evidence and theoretical issues. Psychological Bulletin, 108, 515-532.

Thurstone, L. L., \& Chave, E. J. (1929). The measurement of attitude. Chicago: University of Chicago Press.

U.S. Department of State. (1949). Documents on German foreign policy 1918-1945 Series D. Washington, DC: U.S. Government Printing Office.

U.S. Department of State. (1973, November 19). Department of State Bulletin, 69, 635-655.

Voss, J. F., \& Dorsey, E. (1992). Perception and international relations: An overview. In E. Singer \& V. Hobson (Eds.), Political psychology and foreign policy (pp. 3-30). Boulder, CO: Westview.

Wallace, M. D., Suedfeld, P., \& Thachuk, K. (1993). Political rhetoric of leaders under stress in the Gulf crisis. Journal of Conflict Resolution, 37, 94-107.

Watt, D. C. (1989). How war came: The immediate origins of the Second World War, 1938-1939. New York: Pantheon.

Winter, D. G. (1980). Measuring the motive patterns of southern Africa political leaders at a distance. Political Psychology, 2(2), 75-85.

Winter, D. G. (1991). Measuring personality at a distance: Development of an integrated system for scoring motives in running text. In A. J. Stewart, J. M. Healy, Jr., \& D. J. Ozer (Eds.), Perspectives in personality: Approaches to understanding lives (pp. 59-89). London: Jessica Kingsley.

Winter, D. G. (1992). Personality and foreign policy: Historical overview of research. In E. Singer \& V. Hobson (Eds.), Political psychology and foreign policy (pp. 79-101). Boulder, CO: Westview.

Winter, D. G. (1993). Power, affiliation and war: Three tests of a motivational model. Journal of Personality and Social Psychology, 65, 532545.

Winter, D. G. (1996). Personality: Analysis and interpretation of lives. New York: McGraw-Hill.

Winter, D. G. (1997, July). Comparing "war" and "peace" crises: The role of motivation, responsibility, and integrative complexity. Paper presented at the annual meeting of the International Society of Political Psychology, Kraków, Poland.

Winter, D. G. (1998). "Toward a science of personality psychology:" David McClelland's development of empirically derived TAT measures. History of Psychology, 1, 130-153.

Winter, D. G., \& Stewart, A. J. (1977). Content analysis as a technique for assessing political leaders. In M. G. Hermann (Ed.), A psychological examination of political leaders (pp. 27-61). New York: Free Press.

Woodward, E. L., \& Butler, R. (Ed.). (1949-1954). Documents on British foreign policy 1919-1939, third series (Vols. 1, 2, 4-7). London: His Majesty's Stationery Office.

Wrightsman, L. S., Baxter, G. W., Nelson, R. H., \& Bilsky, L. (1972). Effects of information about the other player and other player's game behavior upon cooperation in a mixed-motive game. In L. S. Wrightsman, J. O'Connor, \& N. J. Baker (Eds.), Cooperation and competition. Readings on mixed-motive games (pp. 213-224). Belmont, CA: Brooks/ Cole. 


\section{Appendix A}

Government-to-Government Communications From Four Crises

\begin{tabular}{|c|c|c|}
\hline Date & Document & Source \\
\hline \multicolumn{3}{|c|}{ Munich crisis (1938) } \\
\hline $5 / 22$ & Henderson letter to Ribbentrop & GD II: 320 \\
\hline $5 / 23$ & Henderson letter to Weizsäcker & GD II: 331 \\
\hline $6 / 10$ & Henderson (Halifax) to Ribbentrop & GD II: 411 \\
\hline $7 / 18$ & Henderson to Weizsäcker & GD II: $490-491$ \\
\hline $7 / 18$ & Cadogan to Captain Wiedemann & BD I: $589-590$ \\
\hline $7 / 20$ & Weizsäcker to Henderson & GD II: $501-502$ \\
\hline $7 / 21$ & Weizsäcker to Halifax (message incorporated in document) & BD I: 609 \\
\hline $7 / 28$ & Halifax to Ribbentrop & BD II: $18-19$ \\
\hline $7 / 29$ & Henderson to Weizsäcker & GD II: 525 \\
\hline $8 / 3$ & Chamberlain to German ambassador & BD II: $4 l$ \\
\hline $8 / 7$ & German ambassador to Chamberlain & BD II: 60 \\
\hline $8 / 11$ & Halifax to Hitler via Henderson & BD II: $78-80$ \\
\hline $8 / 21$ & Ribbentrop to Halifax & BD II: $127-129$ \\
\hline $9 / 9$ & Halifax to Ribbentrop & BD II: $277-278$ \\
\hline $9 / 13$ & Chamberlain to Hitler & BD II: 314 \\
\hline $9 / 19$ & Chamberlain to Hitler & BD II: 406 \\
\hline $9 / 19$ & Weizsäcker to Henderson & GD II: $839-840$ \\
\hline $9 / 19$ & Henderson to Weizsäcker & GD II: $846-847$ \\
\hline $9 / 20$ & Chamberlain to Hitler (via Henderson) & BD II: 424 \\
\hline $9 / 20$ & Ribbentrop to Henderson & BD II: $430-431$ \\
\hline $9 / 20$ & Henderson to Ribbentrop & BD II: $431-432$ \\
\hline $9 / 23$ & Chamberlain to Hitler & BD II: $482-483$ \\
\hline $9 / 23$ & Hitler to Chamberlain & BD II: $485-487$ \\
\hline $9 / 24$ & Chamberlain to Hitler & BD II: 488 \\
\hline $9 / 24$ & German memorandum to Chamberlain & BD II: $495-496$ \\
\hline $9 / 26$ & Chamberlain to Hitler & BD II: $541-542$ \\
\hline $9 / 26$ & Lord Rothermere to Ribbentrop & GD II: 939 \\
\hline $9 / 26$ & Ribbentrop to Lord Rothermere & GD II: $940-941$ \\
\hline $9 / 26$ & Statement by Chamberlain & GD II: 943 \\
\hline $9 / 27$ & Hitler to Chamberlain & BD II: $576-578$ \\
\hline $9 / 27$ & Henderson to Ribbentrop & GD II: $986-988$ (Enclosures 1. \& 2) \\
\hline $9 / 28$ & Chamberlain to Hitler & BD II: 587 \\
\hline
\end{tabular}

Polish crisis (1939)

\begin{tabular}{lll}
$3 / 31$ & Chamberlain "informing" German government (via Henderson) of his 3/31 statement \\
$4 / 27$ & Memorandum to British Foreign Office re: naval agreement & BD IV: 552-553 \\
$5 / 9$ & Henderson statement & BD V: 360-362 \\
$6 / 23$ & Memorandum for transmittal to German Foreign Office & BD VI: 153-158 \\
$8 / 23$ & Chamberlain to Hitler & BD VII: 170-172 \\
$8 / 24$ & Hitler to Chamberlain & BD VII: 177-179 \\
$8 / 25$ & Text of Hitler's verbal communication & BD VII: 330-332 \\
$8 / 28$ & Text of British reply to Hitler & BD VII: 388-390 \\
$8 / 30$ & Text of Hitler's reply to British & BD VII: 403 \\
$8 / 30$ & Halifax to Hitler via Henderson & BD VII: 413-414, 417 \\
$8 / 30$ & Text of British reply to Hitler, as modified & BD VII: 457-458 \\
$8 / 31$ & Weizsäcker to Henderson & BD VII: 459-462 \\
$8 / 31$ & German proposals re: Danzig & BD VII: 488 \\
$9 / 1$ & Halifax to German government & BD VII: 535 \\
$9 / 3$ & British ultimatum & BD VII: 539-541 \\
$9 / 3$ & German reply, via U.S. Berlin Embassy & \\
\hline
\end{tabular}

Bay of Pigs (1961)

\begin{tabular}{lll}
$4 / 6$ & Yuri Lukyanov commentary on U.S. White Paper on Cuba & FBIS, 4/7/61, pp. BB16-17 \\
$4 / 12$ & Kennedy News Conference (Cuba portions) & PPP, pp. 258-265 \\
$4 / 18$ & USSR statement about invasion & CDSP, pp. 3-4 \\
$4 / 18$ & Khrushchev message to Kennedy & CDSP, pp. 4-5 \\
$4 / 18$ & Kennedy message to Khrushchev & PPP, p. 286 \\
$4 / 20$ & Kennedy speech to newspaper editors & PPP, pp. 304-306 \\
$4 / 22$ & Khrushchev message to Kennedy & CDSP, pP. 7-9 \\
\hline
\end{tabular}

Cuban Missile Crisis (1962)

\begin{tabular}{lll}
$10 / 22$ & Kennedy crisis speech & DSB \\
$10 / 23$ & Soviet government statement (via Tass news agency) & New York Times 10/24/62, p. 20 \\
$10 / 22$ & Kennedy to Khrushchev & DSB \\
$10 / 23$ & Khrushchev to Kennedy & DSB \\
$10 / 23$ & Kennedy to Khrushchev & DSB \\
$10 / 24$ & Khrushchev to Kennedy & DSB \\
$10 / 25$ & Kennedy to Khrushchev & DSB \\
$10 / 26$ & Khrushchev to Kennedy & DSB \\
$10 / 27$ & Khrushchev to Kennedy & DSB \\
$10 / 27$ & Kennedy to Khrushchev & DSB \\
$10 / 28$ & Khrushchev to Kennedy & DSB \\
$10 / 28$ & Kennedy to Khrushchev & DSB \\
\hline
\end{tabular}

Note. $\quad \mathrm{BD}=$ Woodward and Butler (1949-1954); CDSP = Current Digest of the Soviet Press, 13(16); DSB = U.S. Department of State (1973, pp. 635-655, "official" Iranslations): FBIS = Foreign Broadcast Information Service Daily Report; GD = U.S. Department of State (1949); PPP $=$ J. F. Kennedy (1961). 


\title{
Appendix B
}

\author{
Template Letter From Khrushchev to Kennedy, October 26, 1962 \\ [Text as received by the U.S. State Department from the U.S.S.R. Embassy]
}

Dear Mr. President:

By now we have already publicly exchanged our assessments of the events around Cuba and each of us has set forth his explanation and his understanding of these events. I think you will understand me correctly [AFF: if you are really concerned for the welfare of the world. Everyone needs peace: both capitalists, if they have not lost their reason, and, all the more communists - people who know how to value not only their own lives but, above all else, the lives of nations]. We communists are against any wars between states at all [AFF: and have been defending the cause of peace ever since we came into the world. We have always regarded war as a calamity, not as a game or a means for achieving particular purposes. much less as a goal in itself. Our goals are clear, and the means of achieving them is work. War is our enemy and a calamity for all nations.

This is how we Soviet people, and together with us, other peoples as well, interpret questions of war and peace. I can say this with assurance at least for the peoples of the Socialist countries, as well as for all progressive people who want peace, happiness, and friendship among nations.

I can see, Mr. President, that you also are not devoid of a sense of anxiety for the fate of the world, not without an understanding and correct assessment of the nature of modern warfare and what war entails. What good would a war do you?] [POW: You threaten us with war. But you well know that the very least you would get in response would be what you had given us; you would suffer the same consequences.] [AFF: That must be clear to us-people invested with authority, trust, and responsibility. We must not succumb to light-headedness and petty passions, regardless of whether elections are forthcoming in one country or another. These are all transitory things.] [POW: Should war indeed break out, it would not be in our power to contain or stop it, for such is the logic of war. I have taken part in two wars, and I know that war only ends when it has rolled through cities and villages, sowing death and destruction everywhere.

You may regard us with distrust, but you can at any rate rest assured that we are of sound mind and understand perfectly well that if we launch an offensive against you, you will respond in kind. But you too will get in response whatever you throw at us. And I think that you also understand that, too.

This indicates that] we are sane people, [POW: that] we understand and assess the situation correctly. How could we, then, allow ourselves the wrong actions which you ascribe to us? Only lunatics or suicides [POW: who themselves want to perish and to destroy the whole world before they die,] could do this. [AFF: But we want to live and by no means do we want to destroy our country.] We want something quite different: to compete with your country [AFF: in a peaceful endeavor]. We argue with you; we have differences on ideological questions. But our concept of the world is that questions of ideology, as well as economic problems, should be settled by other than military means; they must be solved [AFF: in peaceful contest, or, as this is understood in capitalist society-] by competition. [AFF: Our premise has been and remains that peaceful coexistence of two different sociopolitical systems - a reality of our world-is essential, and that it is essential to ensure lasting peace.] These are the principles to which we adhere.

[POW: You have now declared piratical measures, the kind that were practiced in the Middle Ages when ships passing through international waters were attacked, and you have called this a "quarantine" around Cuba. Our vessels will probably soon enter the zone patrolled by your Navy.] I assure you that these vessels which are now headed for Cuba are carrying the most innocuous [AFF: peaceful] cargoes. [POW: Do you really think that all we spend our time on is transporting so-called offensive weapons, atomic and hydrogen bombs?] Even though your military people may possibly imagine that these are some special kind of weapons, I assure you that they are the most ordinary [AFF: kind of peaceful] goods.
Therefore, Mr. President, let us show good sense. I assure you that the ships bound for Cuba are carrying no armaments at all. The armaments needed for the defense of Cuba are already there. I do not mean to say that there have been no shipments of armaments at all. No, there were such shipments. But now Cuba has already obtained the necessary weapons for defense.

[AFF: I do not know whether you can understand me and believe me. But I wish you would believe yourself and agree that one should not give way to one's passions; that one should be master of them.] [POW: If you begin stopping vessels it would be piracy, as you yourself know. If we should start doing this to your ships you would be just as indignant as we and the whole world are now indignant. Such actions cannot be interpreted otherwise, because lawlessness cannot be legalized. Were this] [AFF: Were such actions] allowed to happen then there would be no peace; nor would there be peaceful coexistence. [POW: Then we would be forced to put to take the necessary measures of a defensive nature which would protect our interests in accordance with international law. Why do this?] What would all this lead to? [AFF: Let us normalize relations.]

[POW: You said once that the United States is not preparing an invasion.] [AFF: You have declared that you sympathized with the Cuban emigrants.] [POW: But you have also declared that you will carry out plans against the present government of Cuba. Nor is it any secret to anyone that the constant threat of armed attack and aggression has hung and continues to hang over Cuba.] It is only this that has prompted us to respond to [AFF: the request of the Cuban Government to extend it our aid.] [POW: strengthen the defense capability of that country.]

Let us therefore display statesmanlike wisdom. [CONCESSION: I PROPOSE: WE, FOR OUR PART, WLL DECLARE THAT OUR SHIPS BOUND FOR CUBA ARE NOT CARRYING ANY ARMAMENTS. YOU WILL DECLARE THAT THE UNITED STATES WILL NOT INVADE CUBA WTTH ITS TROOPS AND WILL NOT SUPPORT ANY OTHER FORCES WHICH MIGHT INTEND TO INVADE CUBA.] Then the necessity for the presence of our military specialists in Cuba will be obviated.

[POW: Mr. President, I appeal to you to weigh carefully what the aggressive, piratical actions which you have announced the United States intends to carry out in international waters would lead to. You yourself know that a sensible person simply cannot agree to this, cannot recognize your right to such action.

If you have done this as the first step towards the unleashing of war-well then - evidently nothing remains for us to do but to accept this challenge of yours.] If you have not lost command of yourself and realize clearly what this could lead to, then, Mr. President, you and I should not now pull on the ends of the rope in which you have tied a knot of war, because the harder you and I pull, the tighter this knot will become. And a time may come when this knot is tied so tight that the person who tied it is no longer capable of untying it [POW: and then the knot will have to be cut. What that would mean I need not explain to you, because you yourself understand perfectly what dread forces our two countries possess.]

[AFF: These thoughts are governed by a sincere desire to alleviate the situation and remove the threat of war.]

Respectfully, N. Khrushchev

Note. This version of Khrushchev's letter is a 1,292-word abridgement, slightly modified, from the longer original text of the "informal" transiation published in U.S. Department of State (1973). Sentences containing power and affiliation motive images, here bracketed, underlined, and identified by the labels POW or AFF, were included in the respective motive imagery conditions. The sentences containing Khrushchev's explicit concession, here bracketed, printed in small capitals, and identified with the label CONCESSION, were removed in the "no concession" conditions. 